\title{
MENINGKATKAN PROFESIONALISME GURU \\ SEBAGAI AKTOR UTAMA DALAM DUNIA PENDIDIKAN
}

AULIA RAMA PUTRI

alkhawarizmi@gmail.com

\begin{abstract}
ABSTRAK
Guru adalah pelaku utama dalam dunia pendidikan. Maka dengan hal itu guru diharapkan mampu memberikan peran yang besar serta mengelola proses pembelajaran dengan baik karena proses pembelajaran yang baik akan berdampak pada prestasi belajar siswa. Untuk meningkatkan mutu pendidikan yang sebagian besar dapat dilihat dari prestasi belajar siswa, maka guru adalah sasaran utama yang harus diperbaiki. Dengan meningkatkan keprofesionalismean guru melalui supervisi pendikan diharapakan mampu mengatasi masalah pendidikan dan meningkatkan mutu pendidikan (prestasi belajar siswa menigkat).
\end{abstract}

Kata kunci: Guru, pelaku utama, supervisi pendidikan,prestasi belajar siswa, dan mutu pendidikan.

\section{Latar Belakang}

Pendidikan adalah hal pokok yang akan menopang kemajuan suatu bangsa(M.Or, 2013). Tanpa pendidikan suatu negara akan jauh tertinggal dari negara lain. Kualitas pendidikan di Indonesia pada dewasa ini sangat memprihatinkan. Ini dibuktikan diantaranya oleh data UNESCO (2000) tentang peringkat pencapaian pendidikan, kesehatan, dan penghasilan perkepala yang menunjukkan bahwa indeks pengembangan manusia Inodnesia makin menurun. Diantara 174 negara di dunia, indonesia menempati urutan ke-122 pada 1996. Selain itu bukti nyata dari rendahnya kualitas pendidikan di Indonesia dapat dilihat dari rendahnya prestai belajar siswa. Sebagaimana dikemukakan oleh Sabandi (Sabandi, 2013) Rendahnya pretasi belajar siswa tersebut berkaitan dengan kemampuan guru dalam mengelola pembelajaran.

Berdasarkan uraian diatas, permasalahan dalam tulisan ini adalah apa faktor-faktor yang menyebabkan mutu pendidikan di Indonesia rendah dan bagaimana cara mengatasi masalah mutu pendidikan di Indonesia melalui supervisi pendidikan?.Makalah ini ditulis bertujuan untuk mengetahui penyebab rendahnya mutu Pendidikan di Indonesia dan bagaimana cara untuk mengatasinya melalui supervisi pendidikan. 


\section{Pembahasan}

Upaya untuk meningkatkan mutu pendidikan dipengaruhi oleh banyak faktor. Dimana faktor ini saling berkaitan satu sama lain. Namun demikian faktor yang paling berpengaruh adalah guru, karena guru adalah pelaku utama dalam penerapan program pendidikan di sekolah yang memiliki peran yang sangat penting dalam mencapai tujuan pendidikan yang diharapkan. Guru mempunyai tanggung jawab untuk memperhatikan segala aktivitas siswa dan proses perkembangannya. Maka dengan hal itu guru diharapkan mampu memberikan peran yang besar serta mengelola proses pembelajaran dengan baik karena proses pembelajaran yang baik akan berdampak pada prestasi belajar siswa. Seperti yang dikemukakan oleh Triayuningsih dalam penelitiannya bahwa terdapat hubungan signifikan antara kinerja guru dengan prestasi belajar siswa.

Namun kualitas pendidikan yang rendah justru dipengaruhi oleh kurangnya kemampuan guru dalam mengelola pembelajaran, seperti yang disinyalir Kompasiana (2012) dalam jurnal sabandi (Sabandi, 2013). Bahwa guru tak menanamkan diskusi dua arah serta pembelajaran yang hanya pada buku paket. Tidak dipungkiri adanya guru yang kurang profesional ini akan sangat mengkawatirkan dunia pendidikan. Banyak faktor yang menyebabkan guru kurang profesional, semisal kekurang pahaman guru pada meteri ajar yang disampaikan, bisa juga karena kondisi sekolah yang kurang kondusif untuk proses belajar mengajar, untuk itu kemampuan guru dalam mengajar perlu diperhatikan, mengingat keberhasilan peserta didik banyak bergantung pada kualitas guru sebagai pendidik.

Maka untuk meningkatkan kualitas pendidikan hal pertama yang harus kita benahi adalah menigkatkan kualitas guru yaitu dengan sepervisor.keberadaan suprivisi pendidikan sebagai upaya pengematan kinerja guru agar pekerjaan yang dilakukan bisa berjalan sesuai dengan ketentuan. Untuk itu pengamatan, pemeriksaan, dan pengarahan dimaksudkan hanya untuk melihat bagaimana kegiatan yang dilaksanakan oleh guru mampu mencapai tujuan yang ditentukan(Rahmat, 2013).

Selain itu supervisi pendidikan juga oleh seorang guru yang mengalami berbagai hambatan dengan memberikan bimbingan, pengarahan, dan bantuan dalam mengembangkan potensi dirinya untuk menjadi seorang guru yang profesional. Supervisi pendidikan merupakan kegiatan yang dilakukan secara berulang-ulang dan berkesinambungan sehingga seorang pelaku pendidikan (guru) diharapakan mampu mengembangkan diri dalam mengerjakan tugas dan memecahkan berbagai masalah yang ada dalam dunia pendidikan dan mampu melakukan proses pemebelajaran secara efektif dan efisien.secara imsplisit makna supervisi pendidikan memiliki wawasan dan pandangan baru yakni mengandung 
ide-ide pokok seperti menggalakkkan pertumbuhan profesionalisme guru, mengembangkan kepemimpinan demokratis, serta memecahkan berbagai masalah yang berkaitan dengan efektivitas proses belajar-mengajar. Oleh karena itu supervisi pendidikan sangat penting untuk meningkatkan mutu pendidikan

\section{Penutup}

A. Kesimpulan

Berdasarkan uraian diatas disimpulkan bahwa Kualitas pendidikan di Indonesia masih tergolong sangat rendah, hal ini dapat diakibatkan oleh berbagai faktor. Salah satu faktor yang paling menentukan adalah guru, karena guru adalah aktor utama dalam pendidikan, sehingga untuk meningkatkan kualitas pendidikan yang pertama yang harus dibenahi adalah memperbaiki kualitas guru. Salah satu cara untuk meningkatkan kualitas guru adalah yaitu dengan dupervisi pendidikan.

B. Saran

Berdasarkan pembahasan diatas alangah baiknya untuk meningkatkan kualitas pendidikan maka yang perlu ditingkatkan adalah kualitas guru, yang mana guru adalah aktor utama dalam dunia pendidikan. Peningkatan kualitas guru dapat ditingkatan melalui supervisi pendidikan.

\section{Referensi}

M.Or, S. (2013). Pendidikan di Indonesia. Pedagogik, xv(1), 1-6.

Rahmat, S. (2013). Supervisi pendidikan. Tadris Jurnal Penelitian Dan Pemikiran Islam, 1(1), 1-18. Retrieved from http://stitmatuban.ac.id/wp-content/uploads/2015/10/TD1.3-Supervisi-Pendidikan-H.-S utrisno-Rahmat.pdf

Sabandi, A. (2013). SUPERVISI PENDIDIKAN UNTUK PENGEMBANGAN PROFESIONALITAS GURU BERKELANJUTAN. Pedagogi, Jurnal Ilmiah Ilmu Pendidikan, XIII(2), 1-9. Retrieved from http://ejournal.unp.ac.id/index.php/pedagogi/article/view/4275 